\title{
Characterisation of the prereceptor regulation of glucocorticoids in the anterior segment of the rabbit eye
}

\author{
Claire U Onyimba ${ }^{1,2}$, Neelima Vijapurapu ${ }^{1,2}$, S John Curnow ${ }^{1}$, Pamela Khosla ${ }^{1,2}$, Paul M Stewart ${ }^{2}$, \\ Philip I Murray ${ }^{1}$, Elizabeth A Walker ${ }^{2, *}$ and Saaeha Rauz ${ }^{1, *}$ \\ ${ }^{1}$ Academic Unit of Ophthalmology, Division of Immunity and Infection and ${ }^{2}$ Department of Endocrinology, Division of Medical Sciences, Institute of Biomedical \\ Research, The Medical School, University of Birmingham, Edgbaston, Birmingham B15 5TT, UK \\ (Requests for offprints should be addressed to S Rauz, Birmingham and Midland Eye Centre, Dudley Road, Birmingham B18 7QU, UK; Email: s.rauz@bham.ac.uk) \\ *(E A Walker and S Rauz contributed equally to this work)
}

\begin{abstract}
The prereceptor regulation of glucocorticoids (GCs) by $11 \beta$-hydroxysteroid dehydrogenase type-1 (11ß-HSD1), a bidirectional isozyme that interconverts active (cortisol) and inactive (cortisone) GCs, is an established determinant of GC function in tissues such as liver, adipose and bone. Although the therapeutic use of GCs is abundant in ophthalmic practice, where GC interactions with nuclear receptors modulate gene transcription, the prereceptor regulation of endogenous cortisol is not well described in ocular tissues. Recent descriptive studies have localised $11 \beta$-HSD1 to the human corneal epithelium and non-pigmented epithelium (NPE) of the ciliary body, indicating a link to corneal epithelial physiology and aqueous humour production. In this study, we characterise the functional aspects of the autocrine regulation of GCs in the anterior segment of the rabbit eye. Using our in-house generated primary antibody to human $11 \beta$-HSD1, immunohistochemical analyses were performed on paraffin-embedded sections of whole New Zealand white albino rabbits, (NZWAR) eyes. As in human studies, $11 \beta-H S D 1$ was localised to the corneal epithelium and the NPE. No staining was seen in the albino 'pigmented' ciliary epithelium. Specific enzyme assays for oxo-reductase (cortisone $\rightarrow$ cortisol) and dehydrogenase (cortisol $\rightarrow$ cortisone)
\end{abstract}

activity indicated predominant $11 \beta-\mathrm{HSD} 1$ oxo-reductase activity from both the intact ciliary body tissue $(n=12$, median $2 \cdot 1 \mathrm{pmol} / \mathrm{mg}$ per $\mathrm{h}$ and range $1 \cdot 25-2 \cdot 8 \mathrm{pmol} / \mathrm{mg}$ per h; $P=0 \cdot 006)$ and primary cultures of corneal epithelial cells $(n=12$, median $3.0 \mathrm{pmol} / \mathrm{mg}$ per $\mathrm{h}$ and range $1 \cdot 0-7 \cdot 4 \mathrm{pmol} / \mathrm{mg}$ per h, $P=0 \cdot 008)$ compared with dehydrogenase activity (median $1.0 \mathrm{pmol} / \mathrm{mg}$ per $\mathrm{h}$ and range $0.5-2.0 \mathrm{pmol} / \mathrm{mg}$ per $\mathrm{h}$; median $0.5 \mathrm{pmol} / \mathrm{mg}$ per $\mathrm{h}$ and range $0.25-1.9 \mathrm{pmol} / \mathrm{mg}$ per $\mathrm{h}$ respectively). These findings were supported by expression of $11 \beta-H S D 1$ protein as visualised by Western blotting of ciliary body tissue and immunocytochemistry of corneal epithelial cells. Reduction of corneal epithelial cell proliferation was seen after primary cultures were co-incubated with cortisol and cortisone. 11ßHSD1 activity was not demonstrated in naïve conjunctival fibroblasts or corneal stromal keratocytes. Our results indicate that the distribution of $11 \beta-H S D 1$ in the rabbit resembles that of the human eye and activates cortisone to cortisol in both corneal and uveal tissues. The NZWAR provides a suitable in vivo model for the further evaluation of $11 \beta-H S D 1$ activity in the eye, especially its role in corneal epithelial and ciliary body physiology.

Journal of Endocrinology (2006) 190, 483-493

\section{Introduction}

The cellular actions of glucocorticoids (GCs) are largely mediated through interactions with the glucocorticoid receptor (GR), a nuclear receptor that is found in its inactive form within the cytoplasm. Ligand-receptor binding induces conformational changes within the GR unmasking nuclear localisation signals. Translocation of the ligand-activated GR to hormone response elements in the nuclear chromatin modulates transcription of specific GC-responsive genes (Tsai \& O’Malley 1994, Akner et al. 1995, Czar et al. 1996). The prereceptor regulation of GCs has emerged as a critical determinant of GC function in tissues such as the liver, adipose and bone. Regulation is dependent principally on the expression of a bidirectional isozyme, $11 \beta$-hydroxysteroid dehydrogenase (11 $\beta-H S D 1)$, that interconverts active cortisol and inactive cortisone (Stewart \& Krozowski 1999, Tomlinson et al. 2004). In vivo oxo-reductase activity (cortisone $\rightarrow$ cortisol) predominates through the provision of cofactor (NADPH) by hexose-6-phosphate dehydrogenase, thereby mediating classical GC responses (Draper et al. 2003, Bujalska et al. 2005). Interest in the isozyme has escalated primarily because of its putative role in diseases such as human obesity, insulin resistance and osteoporosis (Kotelevtsev et al. 1997, 
Cooper et al. 2000, Tomlinson et al. 2000, 2004, Bujalska et al. 2002) and also its role in the regulation of immune-cell function and inflammation (Thieringer et al. 2001, Freeman et al. 2005, Zhang et al. 2005). A second dehydrogenase isozyme $(11 \beta-H S D 2)$ protects the mineralocorticoid receptor (MR) from cortisol excess by inactivating it to cortisone (Funder $e t$ al. 1988). This is linked to an inherited form of human hypertension (White et al. 1997, Funder et al. 1988).

Corticosteroids (cortisol and aldosterone) are critical determinants of normal ocular function-mediating processes such as ion transport, gluconeogenesis and immune regulation that are vital for sight. Not only MR and GR, but also $11 \beta$-HSD1, are expressed throughout the human eye (MR: corneal epithelium, endothelium, iris, non-pigmented epithelium (NPE), pigmented epithelium (PE), ciliary body and retinal pigmented epithelium (RPE); and GR: trabecular meshwork (TM), corneal epithelium, corneal endothelium, ciliary body stroma and retina) (Lin et al. 1984, Weinreb et al. 1985, Mirshahi et al. 1996, 1997). Recent descriptive studies have localised this prereceptor regulator of GC function in the human corneal epithelium and ciliary body epithelium (Stokes et al. 2000, Rauz et al. 2001, Suzuki et al. 2001).

The cornea is the transparent window of the eye providing both protective and refractive properties essential for sight. The corneal epithelium is the most superficial layer formed from highly specialised non-keratinised, stratified squamous cells that rapidly proliferate from a peripheral (limbal) stem cell population, replenishing the ocular surface (Dua \& Azuara-Blanco 2000, Daniels et al. 2001, Kinoshita et al. 2001). Recent data have demonstrated the expression of both $11 \beta-H S D 1$ and serum and GC-regulated kinase isoform 1 (SGK1, a downstream marker of GC function) to the basal cells of the corneal epithelium (Rauz et al. 2001, 2003a). SGK1 is also localised to the limbal epithelial cells (Rauz et al. 2003a). As GCs are known to delay wound healing and SGK1 is closely linked to the cell cycle (Buse et al. 1999, Hayashi et al. 2001), 11ß-HSD1 may have a role in corneal epithelial cell renewal and consequently in the management of patients with ocular surface disease.

One of the principal sodium transporting tissues in the human eye is the ocular ciliary epithelium. This is a complex bilayer of pigmented and non-pigmented-polarised, neuroepithelial cells producing aqueous humour (AH) fundamental to the maintenance of intraocular pressure (IOP) and nutrition to the avascular and transparent structures of the eye, such as the cornea, lens and trabecular meshwork. The expression of $11 \beta-H S D 1$ to the NPE of the human ciliary body (Stokes et al. 2000, Rauz et al. 2001, 2003b) is an unexpected finding as $11 \beta-\mathrm{HSD} 2$ is the principal isozyme involved in regulating sodium and water homeostasis in classical sodium transporting epithelia such as the kidney. Nevertheless, studies evaluating the post-receptor pathways in the NPE have identified corticosteroid-mediated expression of SGK1 and epithelial sodium channel subunits (Rauz et al. 2003c). Furthermore, high ratios of $\mathrm{AH}$ cortisol:cortisone reflect a functional intraocular $11 \beta-H S D 1$ (cortisone $\rightarrow$ cortisol) (Rauz et al. 2001, 2003b) and a significant reduction (15-20\%) in IOP following systemic inhibition of 11ß-HSD1 with the non-selective inhibitor, carbenoxolone, has been established in both 'normal' volunteers (Rauz et al. 2001) and patients with low to moderate risk ocular hypertension (patients with raised IOP without optic neuropathy) (Rauz et al. 2003b). In addition, patients with primary open-angle glaucoma (a prevalent, sight-threatening disease associated with uncontrolled IOP and optic nerve damage) exhibit increased peripheral vascular sensitivity to GCs and the ratio of urinary cortisol to cortisone metabolites has been found to be elevated in these patients versus normal controls (Stokes et al. 2003). These data support the role of $11 \beta-H S D s$ in IOP homeostasis and the pathogenesis of primary open-angle glaucoma, thereby providing a possible therapeutic target for the treatment of patients with uncontrolled IOP.

To explore these concepts further, animal models are essential for both endorsing the mechanism underlying our hypotheses linking $11 \beta-H S D 1$ to corneal epithelial physiology and $\mathrm{AH}$ production, and for evaluating novel topical selective $11 \beta-H S D 1$ inhibitors. Although $11 \beta-H S D$ oxoreductase and dehydrogenase activities have been demonstrated in homogenised rat eyes (Stokes et al. 2000), no studies have described tissue- or cell-specific 11 $\beta$-HSD activity in the mammalian eye. A possible animal model for these experiments appears to be the New Zealand white albino rabbit (NZWAR). This is an established model for the investigation of corneal disease (Nakamura et al. 2003, Tungsiripat et al. 2003, Ivarsen et al. 2004, Mimura et al. 2005) and AH dynamics (Tsukahara et al. 1986, Green et al. 1989, Munden \& Schmidt 1992, Lim et al. 2005). The corticosteroid hormone profile is similar to humans (i.e. cortisol rather than corticosterone in rodents). Our study was designed to evaluate the expression of $11 \beta$-HSD1 in the NZWAR ocular tissues and to confirm its suitability as an in vivo model for evaluating the effects of local $11 \beta$ HSD1 expression, primarily in the corneal epithelium and NPE.

\section{Materials and Methods}

\section{Animals and tissues}

Ocular tissues were harvested from 16 NZWAR in a manner consistent with the FRAME Guidelines on research involving the use of laboratory animals, the UFAW Handbook on the care and management of laboratory animals and the $A R V O$ Statement for the use of animals in ophthalmic and vision research. Conjunctiva were surgically dissected and fixed in formalin or stored in a sterile container for primary culture. One globe of each rabbit was fixed in formalin. The remaining globes were bisected in the coronal plane separating the anterior and posterior segments of the eye. The ciliary body 
and corneal scleral rim were carefully dissected from the anterior segment with the aid of a dissecting biomicroscope.

\section{Primary cultures}

Conjunctival fibroblasts Conjunctival specimens were irrigated in sterile PBS in a class II laminar flow cabinet. Each explant was maintained in a single well of a six-well culture plate, in Dulbecco's modified Eagle's medium (DMEM) with glutamax, $1000 \mathrm{mg} / \mathrm{ml}$ glucose and sodium pyruvate (Invitrogen) supplemented with $10 \%(\mathrm{v} / \mathrm{v})$ foetal calf serum (FCS) incubated in a humidified atmosphere set at $37^{\circ} \mathrm{C}$ with $5 \% \mathrm{CO}_{2}$ until outgrowth offibroblasts was observed. Confluent fibroblast cultures were established on day 14 and were subsequently subcultured using trypsin in the conventional manner. All the experiments were carried out on passages 1 and 2 .

Corneal epithelial cells Primary rabbit corneal epithelial cell cultures were derived by incubating corneal-scleral discs for $2 \mathrm{~h}$ at $37^{\circ} \mathrm{C}$ with $1 \cdot 2 \mathrm{IU} / \mathrm{ml}$ neutral protease (Dispase II; Roche). The epithelium was stripped off with gentle scraping from the limbus to the centre into PBS, which was centrifuged at $500 \mathrm{~g}$ for $5 \mathrm{~min}$. The cells were resuspended in keratinocyte medium (Gibco) supplemented with penicillin $100 \mathrm{IU} / \mathrm{ml}$, streptomycin $100 \mathrm{mg} / \mathrm{ml}$, epidermal growth factor $5 \mathrm{ng} / \mathrm{ml}$, bovine pituitary extract $2.5 \mathrm{mg} / \mathrm{ml}$ (Gibco) and FCS 5\%. Cells were cultured in 24-well plates at $37^{\circ} \mathrm{C}$ with $5 \% \mathrm{CO}_{2}$ in $95 \%$ humidified air until $80 \%$ confluent on 7-14 days. No experiments were performed on subcultured cells.

Keratocytes Primary rabbit keratocytes cultures were established by incubating central corneal buttons (trephined from the remnant corneal-scleral disc used for deriving primary corneal epithelial cells) in serum-free conditions consisting of DMEM with glutamax, $1000 \mathrm{mg} / \mathrm{ml}$ glucose and sodium pyruvate (Invitrogen) in a humidified atmosphere set at $37{ }^{\circ} \mathrm{C}$ with $5 \% \mathrm{CO}_{2}$. Confluent keratocyte cultures were established on day 14 and were subsequently subcultured using conventional techniques. All the experiments were carried out on passages 1 and 2 .

\section{Immunocytochemistry}

Primary corneal epithelial cell suspensions were seeded onto chamber slides coated with poly-D-lysine (ICN Biomedicals, Basingstroke, UK) and collagen IV (LGC Promochem, Teddington, UK) and grown until 50\% confluent. The cells were washed with PBS and fixed in precooled methanol by incubating for $10 \mathrm{~min}$ at $-20^{\circ} \mathrm{C}$ followed by further incubation in precooled acetone at $-20^{\circ} \mathrm{C}$ for $1 \mathrm{~min}$. Fixed corneal epithelial cells were washed in tris-buffered saline (TBS) $(3 \times 5 \mathrm{~min})$. The cells were blocked with $5 \%$ normal donkey serum in TBS for $30 \mathrm{~min}$ at $37^{\circ} \mathrm{C}$ in a $\mathrm{CO}_{2}$ incubator and incubated with primary antibody (1:48 for mouse monoclonal anti-CK3 (AE5; ICN Biomedicals); 1:50 for in-house generated human polyclonal anti-11 $\beta$-HSD1) at $37^{\circ} \mathrm{C}$ for $1 \mathrm{~h}$. The cells were washed in TBS $(3 \times 5 \mathrm{~min})$ and incubated with secondary antibody (fluorescin isothiocyanate (FITC)-labelled sheep anti-mouse (Binding Site, Birmingham, UK) for CK3 primary, donkey anti-sheep for $11 \beta$-HSD1 primary, both at $1: 16$ dilution) at $37^{\circ} \mathrm{C}$ for $30 \mathrm{~min}$ in a dark chamber. Finally, the cells were washed in TBS $(3 \times 5 \mathrm{~min})$ and counterstained with Prolong Gold anti-fade reagent with 4' 6'-diamidino-2-phenylindde (DAPI) (Molecular Probes, Invitrogen). The resulting slide was then covered in foil and stored in the refrigerator until visualisation using appropriate filters for DAPI and FITC. Control sections consisted of the use of an irrelevant antibody or antibody pretreated with immunising peptide.

\section{Immunohistochemistry}

Immunohistochemical analyses were performed on $5 \mu \mathrm{m}$ formalin-fixed, paraffin-embedded sections of 16 NZWAR eyes. Immunoperoxidase studies were performed using antisera raised in sheep against human 11ß-HSD1 (amino acids 18-33) and 11ß-HSD2 (amino acids 137-160 and 334-358) as previously reported (Shimojo et al. 1997, Ricketts et al. 1998). Antibody dilutions were 1:100 for $11 \beta-H S D 1$ and 1:200 for 11ß-HSD2. The control sections included the omission of primary antibody and use of antibody pretreated with the immunising peptides. Secondary antibodies comprised donkey anti-sheep peroxidase conjugate (1:100; Binding Site). The sections were visualised with the peroxidase substrate $3,3^{\prime}$-diaminobenzidine. NZWAR liver and kidney sections were used as positive control tissues for $11 \beta$-HSD1 and -2 respectively.

\section{1ß-HSD1 enzyme assays}

Whole tissue ciliary body explants from each eye were divided into quarters and three pieces were placed in three wells of a 24-well plate. The fourth piece of tissue was formalin-fixed and paraffin embedded for confirmatory histology with haematoxylin and eosin. Primary cultures of human conjunctival fibroblasts, keratocytes and corneal epithelial cells were initiated as described earlier, grown to partial confluence in 12-well (conjunctival fibroblasts) and 24-well (keratocytes, corneal epithelial cells) plates. The medium was replaced with serum-free medium $2 \mathrm{~h}$ before incubation with various concentrations of corticosteroids. Dehydrogenase activity (cortisol $\rightarrow$ cortisone conversion) was assessed using $100 \mathrm{nM}$ $\left(3 \cdot 625 \times 10^{-5} \mathrm{mg} / \mathrm{ml}\right)$ unlabelled cortisol (Sigma) diluted in serum-free medium and trace amounts $(1.5 \mathrm{nM})$ of $\left[{ }^{3} \mathrm{H}\right]$ cortisol (specific activity $78.4 \mathrm{Ci} / \mathrm{mmol}$; NEN, Boston, MA, USA) at $37^{\circ} \mathrm{C}$ for $24 \mathrm{~h}$. Conversion of cortisone to cortisol (oxo-reductase) was analysed by incubating cells with $100 \mathrm{nM}$ $\left(3 \cdot 604 \times 10^{-5} \mathrm{mg} / \mathrm{ml}\right)$ unlabelled cortisone and trace amounts of $\left[{ }^{3} \mathrm{H}\right]$ cortisone (50 000 c.p.m.) synthesised in-house as described previously (Bujalska et al. 1997). Whole tissue and primary cultures were incubated with GC 
substrates as described earlier and a 100-fold excess $\left(4 \cdot 707 \times 10^{-3} \mathrm{mg} / \mathrm{ml}\right)$ of glycyrrhetinic acid (GE; Sigma), an inhibitor of $11 \beta-H S D s$ (Monder et al. 1989). After $24 \mathrm{~h}$ incubation, steroids were extracted from the medium with 10 volumes of dichloromethane separated by thin-layer chromatography with chloroform:ethanol (92:8) as a mobile phase and the fractional conversion of cortisol to cortisone or cortisone to cortisol was calculated after scanning analysis using a Bioscan 2000 radioimaging detector (Bioscan, Washington, DC, USA). Following removal of culture medium for enzyme assay, cell monolayers were lysed in $1 \mathrm{ml}$ water for subsequent protein assays. Total protein in each well was determined using a standard protein assay reagent (Bio-Rad) and enzyme activities were expressed as $\mathrm{pmol} / \mathrm{h}$ per mg protein. All assays were carried out in triplicate and data are presented as medians with full ranges analysed by non-parametric statistical methods (Mann-Whitney $U$ and Wilcoxon) using the software packages SSPS for Windows Version 11.5.1 (SPSS, Inc., Chicago, IL, USA, 2002) and Prism for Windows Version 4.03c (GraphPad Software, Inc., San Diego, CA, USA).

\section{Corneal epithelial cell proliferation assays}

Corneal epithelial proliferation was assessed using a commercially available colorimetric assay for determining the number of viable cells (CellTiter 96 AQ ueous $_{\text {One; Promega) according }}$ to the manufacturer's guidelines with appropriate controls (no cells). Cells were coincubated with $100 \mathrm{nM}$ cortisone, cortisone and vehicle plus assay reagents for $1 \mathrm{~h}$ at $37^{\circ} \mathrm{C}$ in a humidified $5 \% \mathrm{CO}_{2}$ atmosphere. The absorbance at $490 \mathrm{~nm}$ reflected the number of living cells and was measured using a 96-well enzyme-linked immunosorbent assay (ELISA) plate reader. Readings were performed in triplicate and the mean no-cell control reading was subtracted from the mean of the cell-containing wells.

\section{Western blot analyses}

Proteins were extracted from ciliary body tissue by cellular disruption in $0 \cdot 1 \mathrm{M}$ Tris- $\mathrm{HCl} \mathrm{pH} 7 \cdot 4,1 \%$ Igepal (SigmaAldrich) $0 \cdot 25 \%$ sodium deoxycholate, and $1 \mathrm{mM}$ EDTA. Total cell extracts were separated by gel electrophoresis and electroblotting onto Immobilon P membrane (Millipore, Watford, Herts, UK). Filters were analysed with specific polyclonal antibodies against the $11 \beta-H S D 1$. Membranes were blocked $\left(1 \mathrm{~h}\right.$ at $\left.25^{\circ} \mathrm{C}\right)$ in PBS plus $0 \cdot 1 \%$ Tween-20 (PBS-T; Sigma) containing 20\% (w/v) non-fat milk powder (Marvel; Premier Brands, Stafford, Staffs, UK) and then rinsed twice in PBS, followed by a further wash in PBS-T for $15 \mathrm{~min}$. Filters were incubated overnight at $4{ }^{\circ} \mathrm{C}$ with the primary antibody diluted 1:500 (11 $\beta$-HSD1) in PBS-T $(0 \cdot 05 \%)$. After three $10-\mathrm{min}$ washes in PBS-T, the filters were incubated with the secondary antibody (horseradish peroxidase-conjugated anti-sheep; Binding Site) diluted 1:25 000 in PBS-T $(0 \cdot 05 \%)$ for $90 \mathrm{~min}$ at $25^{\circ} \mathrm{C}$ and washed for three 10-min periods in PBS-T. Specific 11 $\beta-H S D 1$ protein was detected by the enhanced chemiluminescent assay (ECL; Amersham) after exposure of the filters to radiographic film for 1-20 min. Control experiments were included, where primary antibody was omitted, and filters were exposed to secondary antibody and ECL detection. An additional control was included for the $11 \beta-H S D 1$ antibody, where primary antibody was preadsorbed with an excess of immunising peptide. Human and NZWAR livers were used as positive control tissues and NZWAR kidney as the negative control.

\section{Results}

\section{Primary cultures}

NZWAR conjunctival fibroblasts were established in culture for 14 days and demonstrated characteristic, elongated morphology (Fig. 1A). A confluent monolayer of corneal epithelial cells with distinctive hexahedral architecture was seen between 7 and 14 days of culture (Fig. 1B). Corneal epithelial cells phenotype was confirmed by cytokeratin-3 immunofluorescence staining (Fig. 1C). These cells also expressed 11 $\beta$-HSD1 (Fig. 1D) that was absent when 11ß-HSD1 antibody was preincubated with immunising peptide (Fig. 1E). Following 14 days in culture, outgrowth of stellate-shaped keratocytes could be observed from the central corneal explants (Fig. 1F).

\section{Immunohistochemistry}

Sections of rabbit liver tissue probed with $11 \beta-H S D 1$ antibody revealed intense immunoreactivity within the cells surrounding the central vein (Fig. 2A) consistent with the pattern of staining observed in human liver (Ricketts et al. 1998). This confirmed good cross-species reactivity of the human 11 -HSD1 antibody with rabbit tissues, as seen for the immunocytochemistry analyses of the primary corneal epithelial cells (Fig. 1D). Minimal staining was detected in the liver using the preadsorbed antibody (Fig. 2B). 11ß-HSD1 staining was seen in both corneal and conjunctival epithelia and also corneal endothelium (Fig. $2 \mathrm{C}-\mathrm{E}$ respectively). In the NZWAR ciliary body, 11 $\beta$-HSD1 immunoreactivity was restricted to the NPE layer (Fig. 2F) and could be specifically removed with immunising peptide (Fig. 2G). No staining was observed in the ciliary body using anti-human $11 \beta-H S D 2$ antibody (Fig. $2 \mathrm{H}$ ) despite good cross-reactivity with rabbit tissues confirmed by intense staining of rabbit kidney cortical collecting ducts (Fig. 2I). The conjunctival and corneal tissues did not express 11 $\beta$-HSD2 (data not shown).

\section{$11 \beta-H S D$ assays}

Thin-layer radio-chromatograms (Fig. 3A-C) confirmed predominant oxo-reductase activity in dissected ciliary body tissues (NPE, PE and ciliary body stroma) indicated by a significantly higher substrate conversion of cortisone 

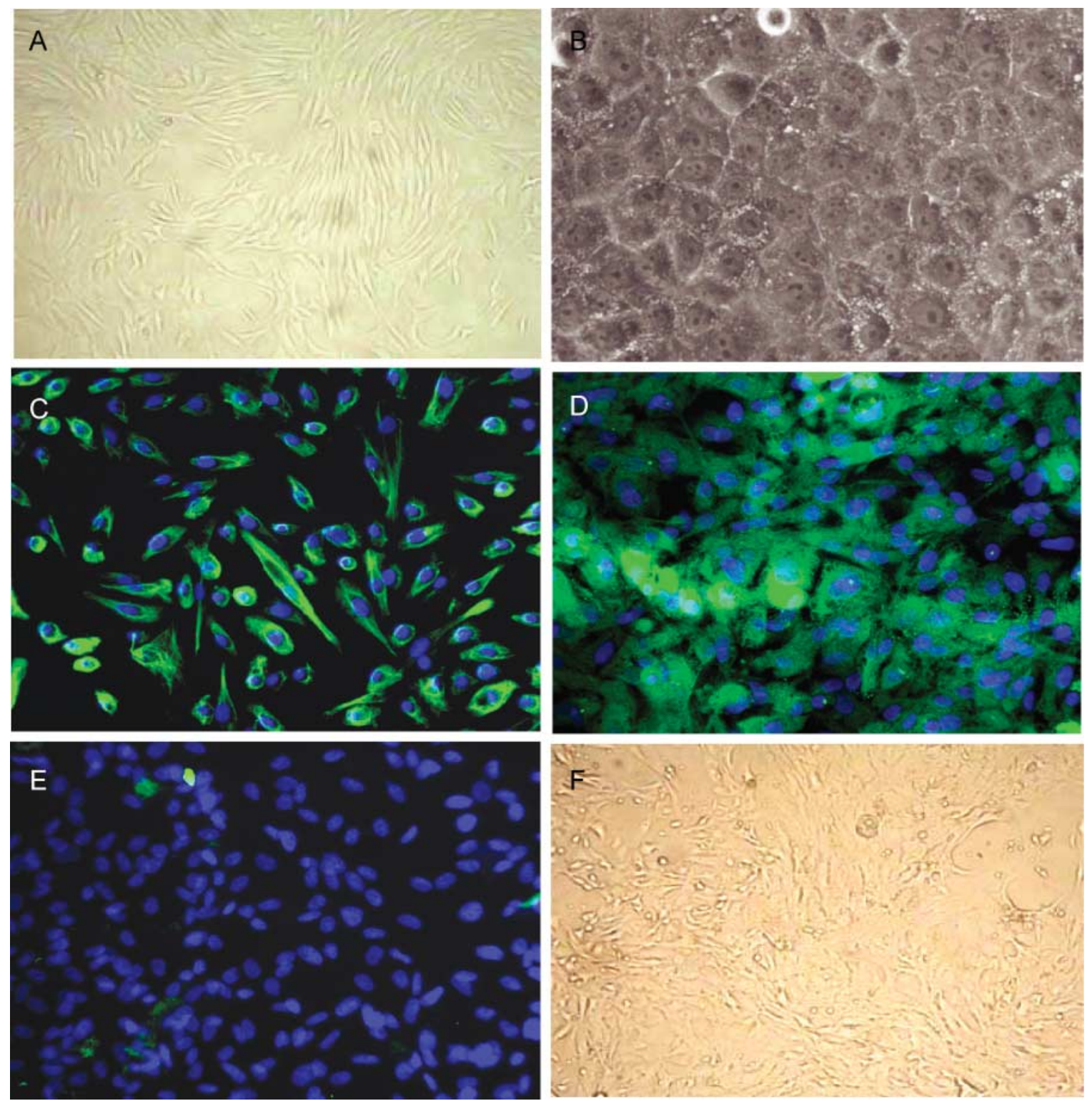

Figure 1 Primary cultures. (A) Confluent conjunctival fibroblasts $(10 \times)$ and (B) corneal epithelial cells $(40 \times)$ are seen on day 14 of establishing primary cultures. (C) Immunocytochemistry for cytokeratin-3 confirmed corneal epithelial phenotype (10X).

(D) Cultured corneal epithelial cells expressed $11 \beta$-hydroxysteroid dehydrogenase type 1 (11 $\beta$-HSD1) that was blocked when (E) cells incubated with $11 \beta$-HSD1 antibody were preadsorbed with immunising peptide $(40 \times)$. (F) Confluent rabbit keratocytes are seen on 14 days of cell culture $(10 \times)$.

to cortisol (median $2 \cdot 1 \mathrm{pmol} / \mathrm{mg}$ per $\mathrm{h}$ and range $1 \cdot 25-2 \cdot 8 \mathrm{pmol} / \mathrm{mg}$ per $\mathrm{h})$ versus cortisol to cortisone conversion (median $0.87 \mathrm{pmol} / \mathrm{mg}$ per $\mathrm{h}$ and range 0 $5-2 \mathrm{pmol} / \mathrm{mg}$ per h), $P=0 \cdot 006$ (Fig. 3D). Coincubation with GE, a 11 $\beta$-HSD1 inhibitor, confirmed a significant reduction of $11 \beta-H S D 1$ oxo-reductase activity (median $0.4 \mathrm{pmol} / \mathrm{mg}$ per $\mathrm{h}$ and range $0 \cdot 2-1 \cdot 2 \mathrm{pmol} / \mathrm{mg}$ per $\mathrm{h}$, $P=0 \cdot 025)$.

Primary cultures Following 24-h incubation, no $11 \beta$ HSD1 activity could be detected from either conjunctival fibroblast or keratocytes primary cultures. Primary corneal epithelial cells demonstrated oxo-reductase activity (median $3 \cdot 0 \mathrm{pmol} / \mathrm{mg}$ per $\mathrm{h}$ and range $1 \cdot 0-7 \cdot 4 \mathrm{pmol} / \mathrm{mg}$ per $\mathrm{h}$ ) that was significantly higher than dehydrogenase activity (median $0.5 \mathrm{pmol} / \mathrm{mg}$ per $\mathrm{h}$ and range $0.4-2.9 \mathrm{pmol} / \mathrm{mg}$ per $\mathrm{h}$ ) after similar 24-h incubation, $P=0 \cdot 008$ (Fig. 4).

\section{Corneal epithelial cell proliferation assays}

Isolated rabbit corneal epithelial cells proliferated rapidly (tenfold increase from baseline) in untreated culture medium 

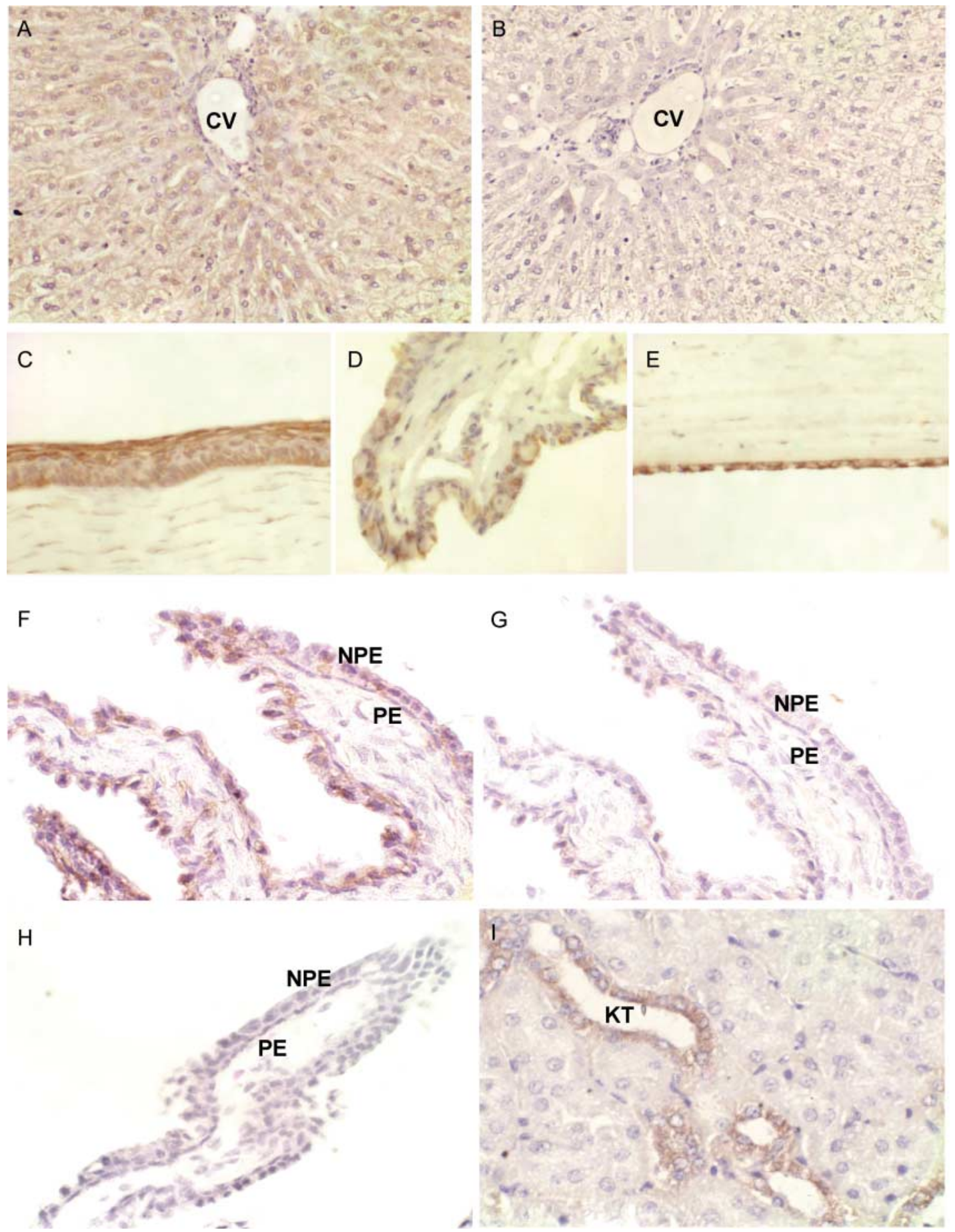

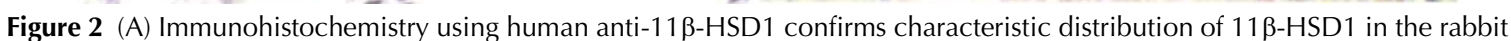
liver surrounding the central vein. (B) No staining was detected using the preadsorbed antibody. $11 \beta$-HSD1 staining was seen in both (C) corneal and (D) conjunctival epithelia and also (E) corneal endothelium. (F) In the ocular ciliary body, 11ß-HSD1 immunoreactivity was restricted to the non-pigmented epithelium (NPE) with the absence of staining in the albino rabbit 'pigmented' ciliary epithelium. (G) NPE staining was specifically reduced with preadsorbed immunising peptide. (H) There was no expression of $11 \beta-$ HSD2 in the ciliary body despite good cross-reactivity with rabbit tissues, confirmed by (I) intense staining of New Zealand white albino rabbit (NZWAR) kidney cortical collecting ducts ( $n=4$ rabbits). CV, central vein; NPE, nonpigmented epithelial cells; PE, pigmented epithelial cells; KT, kidney tubule. 

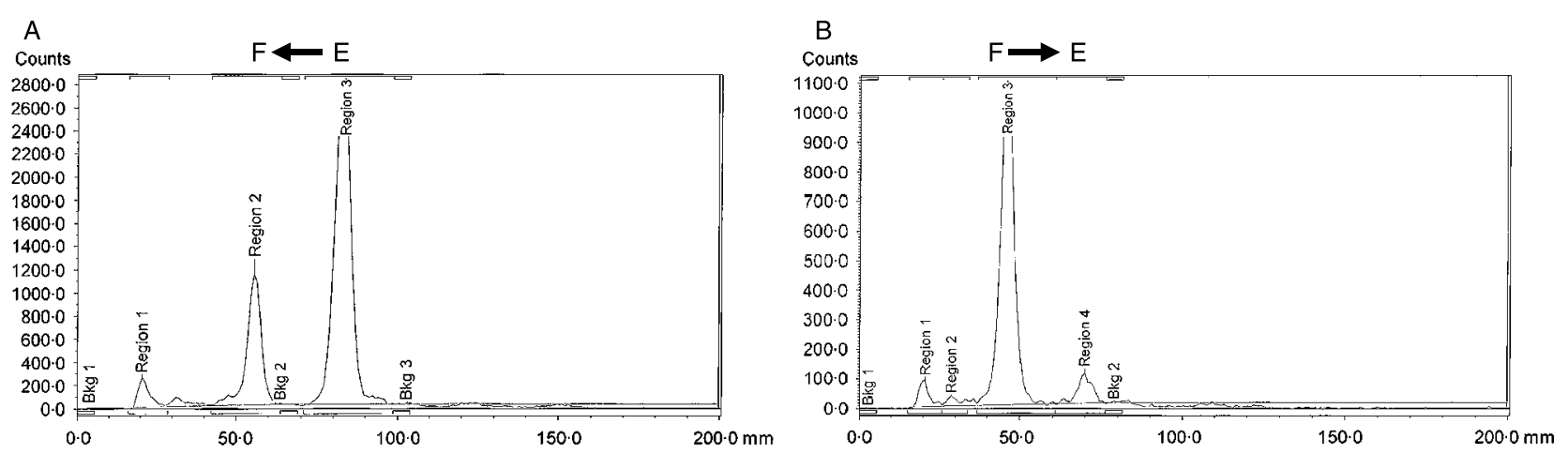

C
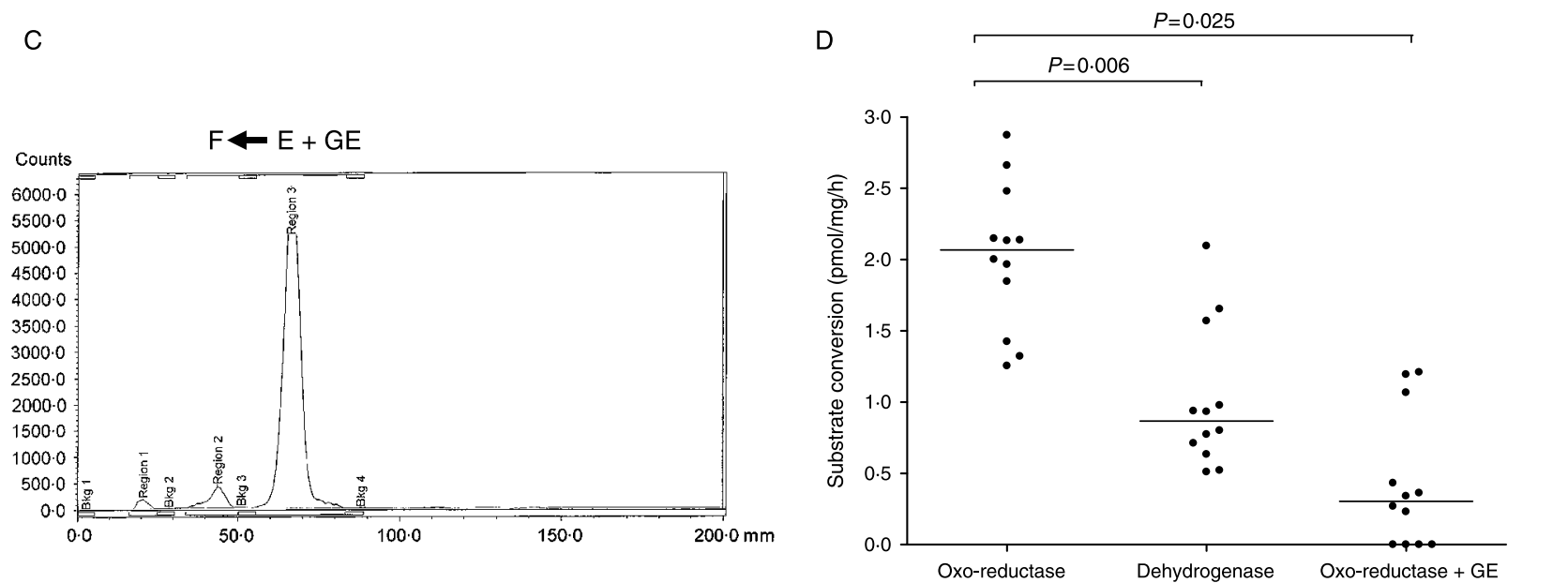

Figure 3 (A) Thin-layer radio-chromatograms showing predominantly $11 \beta$-HSD1 oxo-reductase activity and (B) minimal dehydrogenase activity when dissected ciliary body tissue is incubated for $24 \mathrm{~h}$ with $100 \mathrm{nM}$ cortisone (E) and cortisol (F) respectively. (C) Oxo-reductase activity is reduced in the presence of 100 -fold excess of the $11 \beta$-HSD inhibitor glycyrrhetinic acid (GE). (D) Range plots (median, full range) showing substrate conversion of cortisone to cortisol (oxo-reductase; $n=12$ ) were significantly higher than cortisol to cortisone (dehydrogenase; $n=12$ ) and was inhibited by co-incubation with GE ( $n=12$ rabbits).

(Fig. 5). However, there was a $50 \%$ reduction of cell divisions observed over a 96-h period of culture when cells were coincubated with either cortisone (the inactive GC substrate for $11 \beta$-HSD1) or cortisol (active GC; $P=0 \cdot 008$ ).

\section{Western blot analyses}

Western blot analysis of rabbit and human tissues, using the anti-human 11ß-HSD1 antibody, indicated a high level of cross-species reactivity. A protein band of $34 \mathrm{kDa}$, the expected size of $11 \beta-H S D 1$, was identified in both the human and rabbit liver samples (Fig. 6A). Furthermore, this binding could be blocked using primary antibody preadsorbed with the immunising peptide (Fig. 6B) indicating that these protein bands were specific to $11 \beta-H S D 1$. No band was observed in the rabbit kidney negative control tissue (Fig. 6A). A $34 \mathrm{kDa}$ band was also observed on Western blot analysis of ciliary body tissue (Fig. 6A) that could be blocked by use of primary antibody preincubated with immunising peptide.

\section{Discussion}

$11 \beta$-HSD1 is a tissue-specific prereceptor regulator of the GC responses (Tomlinson et al. 2004). Its importance as a possible therapeutic target in the management of human obesity and insulin resistance is supported by the development of selective 11 $\beta-H S D 1$ inhibitors that improve glucose tolerance in diabetic mice (Alberts et al. 2002, 2003, Barf et al. 2002). In the human eye, the isozyme has been implicated in the pathogenesis of ocular surface disease and glaucoma, the leading causes of worldwide blindness (Stokes et al. 2000, 2003, Rauz et al. 2003a,b).

In human ocular tissues, $11 \beta-\mathrm{HSD} 1$ is localised to the basal cells of the corneal epithelium (Rauz et al. 2001), NPE (Stokes et al. 2000, Rauz et al. 2001, Suzuki et al. 2001) and possibly the trabecular meshwork (Stokes et al. 2000). To explore the expression and activity of this isozyme further in the anterior segment ocular tissues, we turned to an animal model - the NZWAR. This appeared to be the most appropriate model for our studies, as it has been most widely 


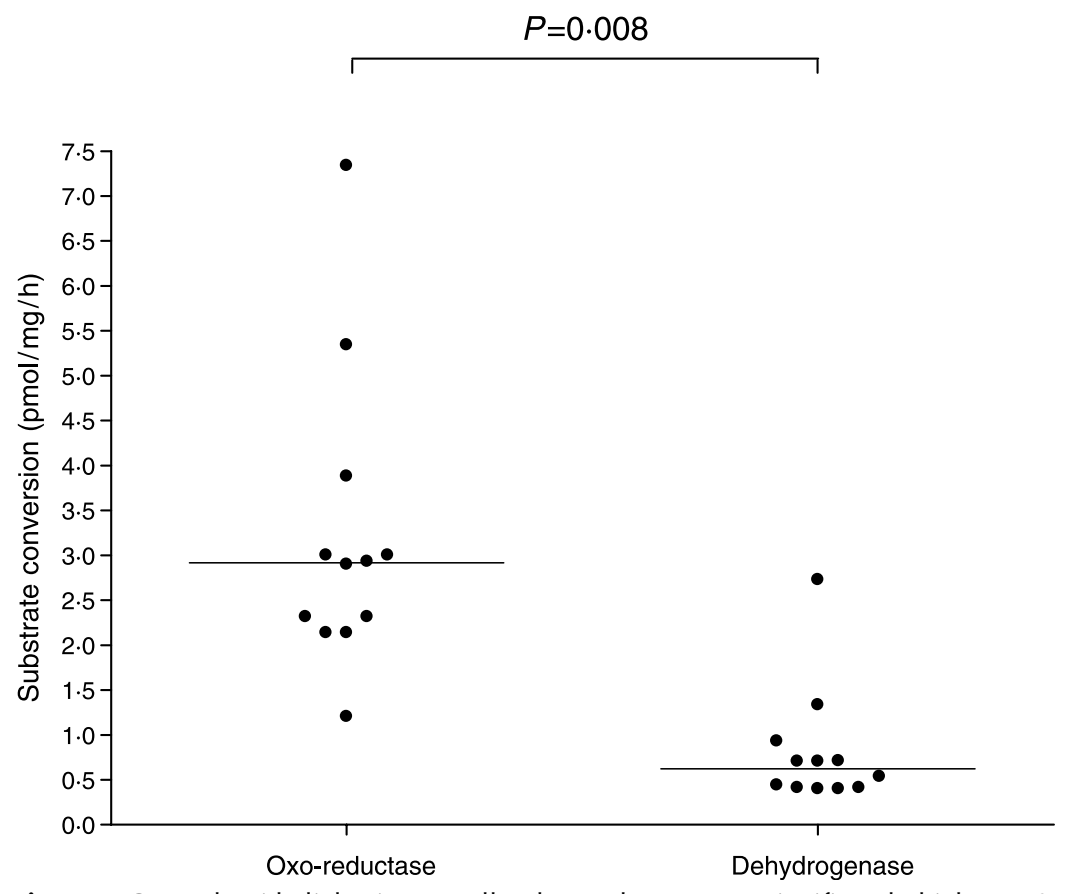

Figure 4 Corneal epithelial primary cell cultures demonstrate significantly higher $11 \beta$ HSD1 oxo-reductase $(n=12)$ activity when compared with dehydrogenase activity $(n=$ 12 rabbits). Range plots (median, full range) show substrate conversion in pmol/mg per $\mathrm{h}$.

used in a variety of in vitro and in vivo experiments investigating both corneal pathophysiology (Becker 1961, Starka et al. 1977, Green et al. 1981, Usukura et al. 1988, Felche \& Sigler 2002, Nakamura et al. 2003, Tungsiripat et al. 2003, Ivarsen et al. 2004, Mimura et al. 2005) and IOP (Becker 1961, Starka et al. 1977, Green et al. 1981, Usukura et al. 1988, Felche \& Sigler 2002, Nakamura et al. 2003, Tungsiripat et al. 2003, Ivarsen et al. 2004, Mimura et al. 2005). Furthermore, our in-house generated polyclonal antibody to human $11 \beta-$ HSD1 shared a $93 \%$ homology to the rabbit $11 \beta-H S D 1$ amino acid sequence and the corticosteroid hormone profile is similar to humans (i.e. cortisol rather than corticosterone in rodents).

The conjunctiva and the cornea are of paramount importance in providing optical clarity and protecting the eye from traumatic insult. The constantly proliferating and differentiating corneal epithelium is known to express SGK1 in the limbal (proliferating) region and both SGK1 and $11 \beta$ HSD1 in the basal (differentiated) layer. In order to investigate the autocrine regulation of the cortisone-cortisol shuttle within the GR-rich ocular surface, we examined specific layers of the NZWAR cornea and conjunctiva.

Immunohistochemistry demonstrated $11 \beta$-HSD 1 expression in the conjunctival and corneal epithelium and, contrary to human studies, the corneal endothelium. Cultured conjunctival fibroblasts did not interconvert cortisone and cortisol, and oxo-reductase and dehydrogenase activity was also absent in naive cultured corneal stromal keratocytes. In contrast, however, cultured corneal epithelial cells, confirmed by cytokeratin-3 staining, expressed $11 \beta-H S D 1$ protein as seen by our immunocytochemistry studies, endorsing findings in earlier human tissues (Stokes et al. 2000, Rauz et al. 2001). In addition, these cells demonstrated predominant $11 \beta$-HSD1 oxo-reductase (cortisone $\rightarrow$ cortisol) activity. Natural and synthetic GCs are known to impair wound healing through interactions with the GR. Our studies confirmed that the rate of corneal epithelial cell proliferation was reduced when the cells were coincubated with the active GC, cortisol. More importantly, however, corneal epithelial cell proliferation was reduced by $50 \%$ when primary cultures were coincubated with inactive GC, cortisone. These data suggest that the local generation of cortisol from cortisone by $11 \beta-H S D 1$ may be a critical feature of corneal epithelial renewal. It is possible that selective $11 \beta$-HSD1 inhibitors may improve epithelial stability in eyes vulnerable to epithelial defects. Furthermore, as $11 \beta-$ HSD 1 is potently regulated by cytokines and active GC is a key component of immune regulation (Thieringer et al. 2001, Freeman et al. 2005, Zhang et al. 2005), the expression of this isozyme in the conjunctival and corneal epithelia and the autocrine regulation of cortisol may be an integral feature of the ocular surface protective barrier. Further studies are now necessary to tease apart the exact role of $11 \beta-H S D 1$ in ocular surface renewal, protection and immune regulation.

The role of $11 \beta$-HSD1 in corticosteroid receptormediated sodium transport in the NPE is an enigma, as in classical tissues such as the kidney and colon, sodium transport is dependent on the mineralocorticoid, aldosterone, where 


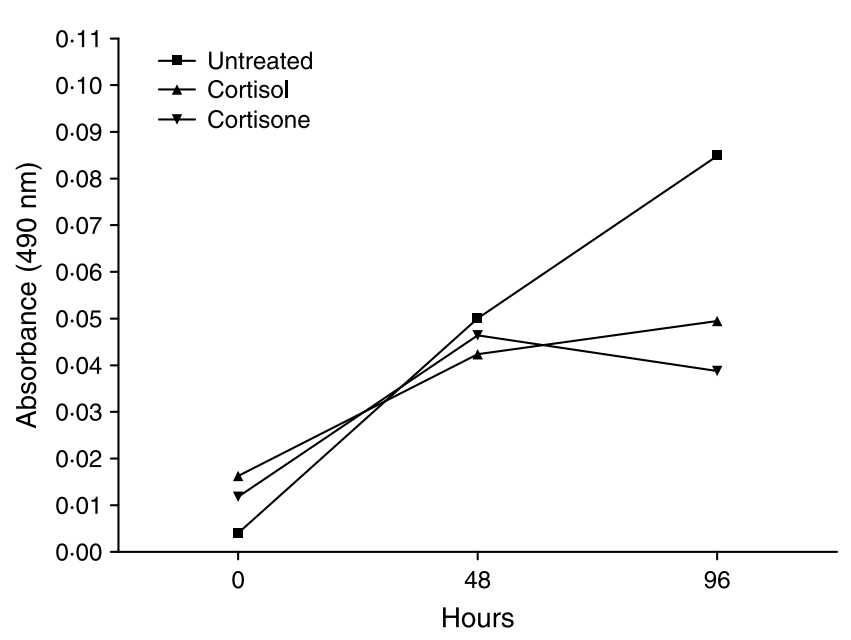

\begin{tabular}{|l|c|}
\hline Treatment & Mean doubling time $(\mathrm{h})$ \\
\hline Untreated & $4 \pm 1.68$ \\
\hline Cortisone & $2 \pm 0.96$ \\
\hline Cortisol & $2 \pm 0.21$ \\
\hline
\end{tabular}

Figure 5 Corneal epithelial cell number estimation using colorimetric cell proliferation assay (CellTitre96 One Solution Proliferation assay; Promega) coincubated with glucocorticoids (GCs). Cell number estimations were performed at 0,48 and $96 \mathrm{~h}$ of culture in serum-containing medium. The optical density at $490 \mathrm{~nm}$ reflects the number of intact viable cells. Proliferation was reduced by $50 \%$ $96 \mathrm{~h}$ after incubation with active (cortisol) and inactive (cortisone) GC $(n=3$ rabbits; $P=0 \cdot 008)$.

$11 \beta-H S D 2$ protects the MR from cortisol excess (by inactivation to cortisone). Nevertheless, in the human intraocular environment, high ratios of $\mathrm{AH}$ cortisol:cortisone indicate a functional intraocular 11 $\beta$-HSD1 (cortisone $\rightarrow$ cortisol) (Rauz et al. 2001, 2003b), endorsed by a reduction in IOP (therefore $\mathrm{AH}$ secretion) after systemic inhibition of

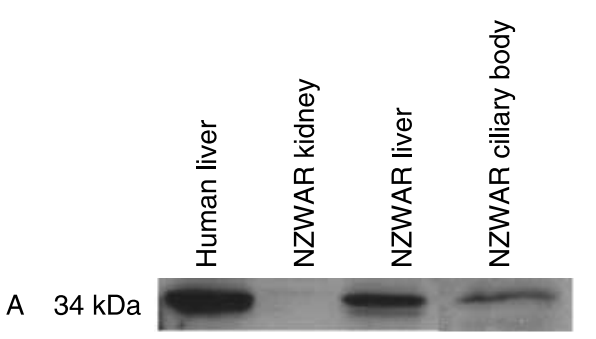

\section{B $34 \mathrm{kDa}$}

Figure 6 Western blot analyses of NZWAR and human tissues using (A) the anti-human $11 \beta$-HSD1 and (B) anti-human 11 $\beta$-HSD1 preadsorbed with immunising peptide. A protein band of $34 \mathrm{kDa}$, the expected size of $11 \beta-$ HSD 1 , was identified in the human liver, NZWAR liver and ciliary body tissue (A) that could be blocked using primary antibody preadsorbed with the immunising peptide. No $34 \mathrm{kDa}$ band was observed in NZWAR kidney.
$11 \beta$-HSD1. Furthermore, both $11 \beta$-HSD1 and -2 activities have been shown in whole rat eye homogenates (Stokes et al. $2000)$ and abnormal urinary corticosteroid metabolites indicative of $11 \beta-H S D$ dysregulation are also seen in patients with primary open-angle glaucoma compared with controls (Stokes et al. 2003).

From these data, it is postulated that the presence of a cortisol-generating system within the human eye may have a twofold role: (i) a short-term physiological role, centred on the sodium-transporting NPE linked to the secretion of AH, maintaining a normotensive, intra-ocular environment, where inhibition of the preceptor $11 \beta$-HSD1 could result in the suppression of $\mathrm{AH}$ formation and a fall in IOP and (ii) a long-term pathological role related to secondary cortisol interactions with the GR within the trabecular meshwork, contributing to aqueous outflow resistance (and raised or uncontrolled IOP) in individuals susceptible to pressure spikes after the use of GCs and the pathogenesis of glaucoma.

There are several ways this hypothesis may be tested. First, by a clinical study designed to show a reduction in intraocular circulating AH cortisol paralleling the reduction in IOP after treatment with systemic carbenoxolone (a non-selective inhibitor of the $11 \beta-H S D s)$, we confirm the inhibition of intraocular $11 \beta-H S D 1$ and therefore AH production. This study is not possible as serial AH sampling in the healthy eye would not merit ethical approval. An alternative is to move to an established in vitro model for evaluating NPE pathophysiology, the ODM-2 NPE cell line (Martin-Vasallo et al. 1989, Civan et al. 1996, Carre et al. 2000, Rauz et al. 2003c). Our preliminary studies, however, failed to demonstrate 11ß-HSD1 oxo-reductase or dehydrogenase activity (S Rauz \& E A Walker, unpublished observations) despite the expression at a mRNA level (Rauz et al. 2001). One reason for this anomaly is that ODM-2 is a simian virus-transformed cell line and the transformation process may alter the molecular and cellular characteristics of the cell including $11 \beta-H S D 1$ activity. It has also been well documented that there is a switch in isozyme expression from $11 \beta-H S D 1$ to -2 in proliferating cell lines in culture (Rabbitt et al. 2002, 2003). Finally, we considered the anatomy of the ciliary body, which is a highly complex tissue consisting of an outer NPE layer that communicates with the PE forming an anatomical and physiological syncytium overlying a vascular stroma. We hypothesised that $11 \beta$-HSD1 function in the NPE is dependent on interactions with the PE and the stroma. By taking precedence from the methodology described in earlier studies establishing a cortisone-activating enzyme in hepatic tissue lysates (Lakshmi \& Monder 1988) and ocular homogenates (Stokes et al. 2000), we progressed onto the use of whole ciliary body explants dissected from an animal model for our in vitro analyses described in this present study. In this manner, an attempt was made to maintain the functional syncytium that was confirmed by histological analysis. In order to minimise the preferential $11 \beta$-HSD1 dehydrogenase activity in vitro that limits the use of tissue 
lysates, we carefully dissected ciliary body tissue so that there was minimal cellular destruction.

Our data have confirmed the expression of $11 \beta-H S D 1$ isozyme to the outer NPE layer. For the first time, we have confidently defined the absence of expression of either isozyme within the inner PE, as the NZWAR is devoid of pigment and thus cannot mask visualisation of the secondary antibody. Most importantly, enzyme assays on the intact ciliary body tissue have endorsed predominant oxo-reductase (cortisone $\rightarrow$ cortisol) activity and hence this activity is reduced when incubated with an 11ß-HSD1 inhibitor. As immunohistochemistry confirmed the absence of $11 \beta-H S D 2$ expression in the NPE and PE, the minimal dehydrogenase activity was attributed to surgical dissection and tissue necrosis driving the isozyme in a dehydrogenase direction and possibly to $11 \beta-\mathrm{HSD} 2$ dehydrogenase activity from the vascular fraction of the stroma. These data provide evidence that an active $11 \beta-H S D 1$ is a feature of ciliary body physiology, providing a rationale for further characterisation of the NZWAR as a model to evaluate selective topical $11 \beta$-HSD1 inhibitors as a putative treatment for glaucoma.

In summary, the distribution of $11 \beta-H S D 1$ in the NZWAR eye resembles that of the human eye. This isozyme activates cortisone to cortisol in both ciliary body tissue and corneal epithelium. The NZWAR provides a suitable in vivo model for the further evaluation of $11 \beta-H S D 1$ activity in the eye, especially its role in the regulation of IOP and corneal epithelial physiology.

\section{Acknowledgements}

This work forms the basis of an International Patent Application (No. 9914648.2). The authors declare that there is no conflict of interest that would prejudice the impartiality of this scientific work.

\section{Funding}

This work was funded by Medical Research Council, UK and Wellcome Trust, UK.

\section{References}

Akner G, Wikström A-C \& Gustafsson J-Ä 1995 Subcellular distribution of the glucocorticoid receptor and evidence for its association with microtubules. Journal of Steroid Biochemistry 52 1-16.

Alberts P, Engblom L, Edling N, Forsgren M, Klingström G, Larsson C, Rönquist-Nii Y, Öhman B \& Abrahmsén L 2002 Selective inhibition of $11 \beta$-hydroxysteroid dehydrogenase type 1 decreases blood glucose concentrations in hyperglycaemic mice. Diabetologia 45 1528-1532.

Alberts P, Nilsson C, Selen G, Engblom L, Edling N, Norling S, Klingstrom G, Larsson C, Forsgren M, Ashkzari M et al. 2003 Selective inhibition of $11 \beta-$ hydroxysteroid dehydrogenase type 1 improves hepatic insulin sensitivity in hyperglycemic mice strains. Endocrinology 144 4755-4762.

Barf T, Vallgårda J, Emond R, Haggstrom C, Kurz G, Nygren A, Larwood V, Mosialou E, Axelsson K, Olsson R et al. 2002 Arylsulfonamidothiazoles as a new class of potential antidiabetic drugs, discovery of potent and selective inhibitors of the $11 \beta$-hydroxysteroid dehydrogenase type 1. Journal of Medicinal Chemistry 45 2813-2815.

Becker B 1961 The turnover of iodine in the rabbit eye. Archives of Ophthalmology 65 832-836.

Bujalska I, Shimojo M, Howie A \& Stewart PM 1997 Human 11ßhydroxysteroid dehydrogenase: studies on the stably transfected isoforms and localization of the type 2 isozyme within renal tissue. Steroids 77 77-82.

Bujalska IJ, Walker EA, Hewison M \& Stewart PM 2002 A switch in dehydrogenase to reductase activity of $11 \beta$-hydroxysteroid dehydrogenase type 1 upon differentiation of human omental adipose stromal cells. Journal of Clinical Endocrinology and Metabolism 87 1205-1210.

Bujalska I, Draper N, Michialidou Z, Tomlinson JW, White PC, Chapman KE, Walker EA \& Stewart PM 2005 Hexose-6-phosphate dehydrogenase confers oxo-reductase activity upon $11 \beta$-hydroxysteroid dehydrogenase type 1. Journal of Molecular Endocrinology 35 675-684.

Buse P, Tran SH, Luther E, Phu PT, Aponte GW \& Firestone GL 1999 Cellcycle and hormonal control of nuclear cytoplasmic localization of the serum- and glucocorticoid-inducible protein kinase, sgk, in mammary tumor cells: a novel convergence point of antiproliferative and proliferative cell signaling pathways. Journal of Biological Chemistry 274 7253-7263.

Carre DA, Mitchell CH, Peterson-Yantorno K, Coca-Prados M \& Civan MM 2000 Similarity of $\mathrm{A}_{3}$-adenosine and swelling-activated $\mathrm{Cl}^{-}$channels in nonpigmented ciliary epithelial cells. American Journal of Physiology 279 C440-C451.

Civan MM, Coca-Prados M \& Peterson-Yantorno K 1996 Regulatory volume increase of human non-pigmented ciliary epithelial cells. Experimental Eye Research 62 627-640.

Cooper MS, Walker EA, Bland R, Fraser WD, Hewison M \& Stewart PM 2000 Expression and functional consequences of $11 \beta$-hydroxysteroid dehydrogenase activity in human bone. Bone 27 375-381.

Czar MJ, Welsh MJ \& Pratt WB 1996 Immunofluorescent localization of the $90 \mathrm{k}-\mathrm{Da}$ heat-shock protein to cytoskeleton. European Journal of Cell Biology $70322-330$.

Daniels JT, Dart JKG, Tuft SJ \& Khaw PT 2001 Corneal stem cells in review. Wound Repair and Regeneration 9 483-484.

Draper N, Walker EA, Bujalska IJ, Tomlinson JW, Chalder SM, Arlt W, Lavery GG, Bedendo O, Ray DW, Laing I et al. 2003 Mutations in the genes encoding 11beta-hydroxysteroid dehydrogenase type 1 and hexose-6phosphate dehydrogenase interact to cause cortisone reductase deficiency. Nature Genetics 34 434-439.

Dua HS \& Azuara-Blanco A 2000 Limbal stem cells of the corneal epithelium. Survey of Ophthalmology 44 415-425.

Felche LM \& Sigler RL 2002 Phacoemulsification for the management of Encephalitizoon cuniculi-induced phacoclastic uveitis in a rabbit. Veterinary Ophthalmology 5 211-215.

Freeman L, Hewison M, Hughes SV, Evans KN, Hardie D, Means TK \& Chakraverty R 2005 Expression of $11 \beta$-hydroxysteroid dehydrogenase type 1 permits regulation of glucocorticoid bioavailability by human dendritic cells. Blood 106 2042-2049.

Funder JW, Pearce PT, Smith R \& Smith AI 1988 Mineralocorticoid action: target tissue specificity is enzyme, not receptor, mediated. Science $\mathbf{2 4 2}$ $583-585$.

Green K, Symonds CM, Elijah RD, Zalkow LH, Deutsch HM, Bowman KA \& Morgan TR 1981 Water soluble marihuana-derived material; pharmacological actions in rabbit and primate. Current Eye Research $\mathbf{1}$ 599-608.

Green K, Cheeks L, Slagle T \& Phillips CI 1989 Interaction between progesterone and mifepristone on intraocular pressure in rabbits. Current Eye Research 8 317-320.

Hayashi M, Tapping RI, Chao T, lo J, King CC, Yang Y \& Lee J 2001 BMK1 mediates growth factor-induced cell proliferation through direct cellular activation of serum and glucocorticoid inducible kinase. Journal of Biological Chemistry 276 8631-8634.

Ivarsen A, Laurberg T \& Moller-Pedersen T 2004 Role of keratocyte loss on corneal wound repair after LASIK. Investigative Ophthalmology and Visual Science 45 3499-3506. 
Kinoshita S, Adachi W, Sotozono C, Nishida K, Yokoi N, Quantock AJ \& Okubo K 2001 Characteristics of the human ocular surface epithelium. Progress in Retinal and Eye Research 20 639-673.

Kotelevtsev Y, Holmes MC, Burchell A, Houston PM, Schmoll D, Jamieson P, Best R, Brown R, Edwards CRW, Seckl JR et al. 1997 11ß-hydroxysteroid dehydrogenase type 1 knockout mice show attenuated glucocorticoidinducible responses and resist hyperglycaemia on obesity and stress. PNAS 94 14924-14929.

Lakshmi V \& Monder C 1988 Purification and characterization of the corticosteroid $11 \beta$-dehydrogenase component of the rat liver $11 \beta$ hydroxysteroid dehydrogenase complex. Endocrinology 124 2390-2398.

Lim KS, Wickremasinghe SS, Cordeiro MF, Bunce C \& Khaw PT 2005 Accuracy of intraocular pressure measurements in New Zealand white rabbits. Investigative Ophthalmology and Visual Science 46 2419-2423.

Lin MT, Eiferman RA \& Wittliff JL 1984 Demonstration of specific glucocorticoid binding sites in bovine cornea. Experimental Eye Research 38 333-339.

Martin-Vasallo P, Ghosh S \& Coca-Prados M 1989 Expression of Na,KATPase alpha subunit isoforms in the human ciliary body and cultured ciliary epithelial cells. Journal of Cellular Physiology 141 243-252.

Mimura T, Yamagami S, Yokoo S, Araie M \& Amano S 2005 Comparison of rabbit corneal endothelial cell precursors in the central and peripheral cornea. Investigative Ophthalmology and Visual Science 46 3645-3648.

Mirshahi M, Nicolas C, Mirshahi A, Hecquet C, d'Hermies F, Faure JP \& Agrawal MK 1996 The mineralocorticoid hormone receptor and action in the eye. Biochemical and Biophysical Research Communications 219 150-156.

Mirshahi M, Mirshahi A, Sedighian R, Hecquet C, Faure JP \& Agarawal MK 1997 Immunochemical demonstration of the mineralocorticoid receptor. Neuroendocrinology 65 70-78.

Monder C, Stewart PM, Lakshmi V, Valentino R, Burt D \& Edwards CRW 1989 Licorice inhibits corticosteroid $11 \beta$-dehydrogenase of rat kidney and liver: in vivo and in vitro studies. Endocrinology 125 1046-1053.

Munden PM \& Schmidt TJ 1992 Mifepristone blocks specific glucocorticoid receptor binding in rabbit iris-ciliary body. Archives of Ophthalmology 110 703-705.

Nakamura T, Endo K-I, Cooper LJ, Fullwood NJ, Tanifuji N, Tsuzuki M, Koizumi N, Inatomi T, Sano Y \& Kinoshita S 2003 The successful culture and autologous transplantation of rabbit oral mucosal epithelial cells on amniotic membrane. Investigative Ophthalmology and Visual Science 44 106-116.

Rabbitt EH, Lavery GG, Walker EA, Cooper MS, Stewart PM \& Hewison M 2002 Prereceptor regulation of glucocorticoid action by $11 \beta$-hydroxysteroid dehydrogenase: a novel determinant of cell proliferation. FASEB Journal 16 36-44.

Rabbitt EH, Gittoes NJL, Stewart PM \& Hewison M $200311 \beta$ Hydroxysteroid dehydrogenases, cell proliferation and malignancy. Journal of Steroid Biochemistry and Molecular Biology 85 415-421.

Rauz S, Walker EA, Shackleton CHL, Hewison M, Murray PI \& Stewart PM 2001 Expression and putative role of $11 \beta$-hydroxysteroid dehydrogenase isozymes within the human eye. Investigative Ophthalmology and Visual Science 42 2037-2042.

Rauz S, Walker EA, Murray PI \& Stewart PM 2003a Expression and distribution of the serum and glucocorticoid regulated kinase and epithelial sodium channel subunits in the human cornea. Experimental Eye Research $\mathbf{7 7}$ 101-108.

Rauz S, Cheung CMG, Wood PJ, Coca-Prados M, Walker EA, Murray PI \& Stewart PM $2003 b$ Inhibition of $11 \beta$-hydroxysteroid dehydrogenase type 1 lowers intraocular pressure in patients with ocular hypertension. Quarterly Journal of Medicine 96 481-490.

Rauz S, Walker EA, Hughes SV, Coca-Prados M, Hewison M, Murray PI \& Stewart PM 2003c Serum- and glucocorticoid-regulated kinase isoform-1 and epithelial sodium channel subunits in human ocular ciliary epithelium. Investigative Ophthalmology and Visual Science 44 1643-1651.
Ricketts ML, Verhaeg JM, Bujalska I, Howie AJ, Rainey WE \& Stewart PM 1998 Immunohistochemical localization of type $111 \beta$-hydroxysteroid dehydrogenase in human tissues. Journal of Clinical Endocrinology and Metabolism 83 1325-1335.

Shimojo M, Ricketts ML, Perelli MD, Moradi P, Johnson GD, Bradwell AR, Hewison M, Howie AJ \& Stewart PM 1997 Immunodetection of $11 \beta-$ hydroxysteroid dehydrogenase type 2 in human mineralocorticoid target tissues: evidence of nuclear localizaton. Endocrinology 138 1305-1311.

Starka L, Hampl R, Gregorova I \& Obenberger J 1977 Aldosterone: its occurrence, metabolism and binding in the rabbit eye. Experimental Eye Research 25 91-98.

Stewart PM \& Krozowski ZS 1999 11ß-Hydroxysteroid dehydrogenase. Vitamins and Hormones 57 249-324.

Stokes J, Noble J, Brett L, Philips C, Seckl JR, O’Brien C \& Andrew R 2000 Distribution of glucocorticoid and mineralocorticoid receptors and $11 \beta$ hydroxysteroid dehydrogenases in human and rat ocular tissues. Investigative Ophthalmology and Visual Science 41 1629-1638.

Stokes J, Walker BR, Campbell JC, Seckl JR, O’Brien C \& Andrew R 2003 Altered peripheral sensitivity to glucocorticoids in primary open-angle glaucoma. Investigative Ophthalmology and Visual Science 44 5163-5167.

Suzuki T, Sasano H, Kaneko C, Ogawa S, Darnel AD \& Krozowski ZS 2001 Immunohistochemical distribution of $11 \beta$-hydroxysteroid dehydrogenase in human eye. Molecular and Cellular Endocrinology 173 121-125.

Thieringer R, Grande CBL, Carbin L, Cai T, Wong B, Wright SD \& Hermanowski-Vosatka A 2001 11ß-Hydroxysteroid dehydrogenase type 1 is induced in human monocytes upon differentiation to macrophages. Journal of Immunology 167 30-35.

Tomlinson JW, Bujalska I, Stewart PM \& Cooper MS 2000 The role of $11 \beta$ hydroxysteroid dehydrogenase in central obesity and osteoporosis. Endocrine Research 26 711-722.

Tomlinson JW, Walker EA, Bujalska IJ, Draper N, Lavery GG, Cooper MS, Hewison M \& Stewart PM 2004 11ß-Hydroxysteroid dehydrogenase type 1: a tissue-specific regulator of glucocorticoid response. Endocrine Reviews 25 831-866.

Tsai M-J \& O'Malley BW 1994 Molecular mechanisms of action of steroid/thyroid receptor superfamily members. Annual Review of Biochemistry 63 451-486.

Tsukahara S, Sasaki T, Phillips CI \& Gore SM 1986 Subconjunctival suspension of RU486 lowers intraocular pressure in normal rabbits. British Journal of Ophthalmology 70 451-455.

Tungsiripat T, Sarayba MA, Kaufman MB, Sweet PM, Taban M, Carpenter TR \& McDonnell PJ 2003 Fluoroquinolone therapy in multiple-drug resistant staphylococcal keratitis after lamellar keratectomy in a rabbit model. American Journal of Ophthalmology 136 76-81.

Usukura J, Fain GL \& Bok D $1988\left[{ }^{3} \mathrm{H}\right]$ Oubain localization of Na-K ATPase in the epithelium of rabbit ciliary body pars plicata. Investigative Ophthalmology and Visual Science 29 606-614.

Weinreb RN, Polansky JR, Kramer SG \& Baxter JD 1985 Acute effects of dexamethasone on intraocular pressure in glaucoma. Investigative Ophthalmology and Visual Science 26 170-175.

White PC, Mune T \& Agarwal AK 1997 11 $\beta$-Hydroxysteroid dehydrogenase and the syndrome of mineralocorticoid excess. Endocrine Reviews $\mathbf{1 8}$ 135-156.

Zhang TY, Ding X \& Daynes RA 2005 The expression of $11 \beta$-hydroxysteroid dehydrogenase type I by lymphocytes provides a novel means for intracrine regulation of glucocorticoid activities. Journal of Immunology 174 879-889. Received in final from 22 April 2006
Accepted 27 April 2006 